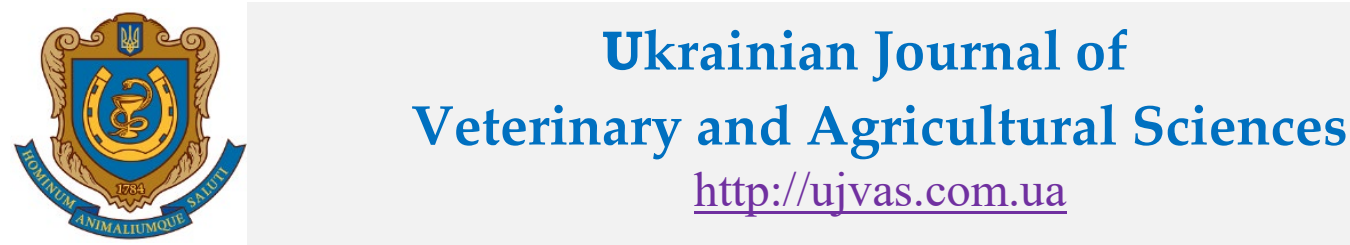

Stepan Gzhytskyi National University of Veterinary Medicine and Biotechnologies Lviv original article $\mid$ UDC 619:617:619.612:636,2 | doi: 10.32718/ujvas3-1.10

\title{
Expression of plasmolemma proteins of the absorptive enterocytes of the cattle in the late fetal period
}

\author{
D. M. Masiuk
}

Dnipro State Agrarian and Economic University, Serhii Efremov Str., 25, Dnipro, 49600, Ukraine

\begin{tabular}{|c|c|}
\hline $\begin{array}{l}\text { Article info } \\
\text { Received } 10.02 .2020 \\
\text { Received in revised form } \\
\quad 10.03 .2020 \\
\text { Accepted } 11.03 .2020\end{array}$ & \\
\hline $\begin{array}{l}\text { Correspondence author } \\
\text { Dmytro Masiuk } \\
\text { Tel.: +38-050-636-62-37 } \\
\text { E-mail: dimasiuk@gmail.com }\end{array}$ & \\
\hline $\begin{array}{l}2020 \text { Masiuk D. M. This is an o } \\
\text { access article distributed unde } \\
\text { terms of the Creative Comr } \\
\text { Attribution License, which per } \\
\text { unrestricted use, distribution, } \\
\text { reproduction in any med } \\
\text { provided the original author } \\
\text { source are credited. }\end{array}$ & $\begin{array}{l}\text { pen- } \\
r \text { the } \\
\text { mons } \\
\text { rmits } \\
\text { and } \\
\text { lium, } \\
\text { and }\end{array}$ \\
\hline$(\mathrm{cc}) \mathrm{BY}$ & \\
\hline \multicolumn{2}{|l|}{ Contents } \\
\hline 1. Introduction .................. & 52 \\
\hline 2. Materials and methods ....... & 53 \\
\hline 3. Results and discussion ...... & 53 \\
\hline 4. Conclusions .................. & 56 \\
\hline References ..................... & 56 \\
\hline
\end{tabular}

\begin{abstract}
The article presents new scientific data on the expression of plasmalemma proteins of the absorptive enterocytes of the bovine intestines of five to nine months of age. In the late fetal period, 31 and 27 protein fractions of apical and basolateral membranes, respectively, were found in the plasmalemma of the jejunum intestine, which had a molecular weight of $9.6 \mathrm{kDa}$ to $300 \mathrm{kDa}$. Twenty-nine protein fractions were detected in the apical membranes of five-month-old cattle enterocytes. It should be noted that protein fractions with low molecular weight (up to 24 $\mathrm{kDa}$ ) were only $19.7 \%$, with molecular weights from $24 \mathrm{kDa}$ to $100 \mathrm{kDa}-69.2 \%$, and fractions with molecular weights of $100 \mathrm{kDa}$ and more were detected only $-11.1 \%$ of the total number of polypeptides. Twenty-five protein fractions with a molecular weight of 9.6 to $155 \mathrm{kDa}$ were found in the basolateral enterocyte membranes of five-month-old fetus. A large proportion of the detected protein fractions belonged to low molecular weight polypeptides (9.6-24 kDa-40.26\%). Proteins with a molecular weight of 24-95 kDa - 55.2\%, with a molecular mass of $100 \mathrm{kDa}$ and more were found only $4.56 \%$. High molecular weight proteins in the basolateral membrane of jejunum enterocytes of five-months-old cattle with a molecular weight greater than $155 \mathrm{kDa}$ were not detected by electrophoresis (unlike the apical membrane). Analysis of the results of studies membranes protein of cattle enterocytes in late fetal period indicates significant changes in their polypeptide composition. In particular, in the basolateral membranes of enterocytes during the late fetal period there is a decrease in the content of low molecular weight protein fractions (3.3 times; $\mathrm{P} \leq 0.001)$ and an increase in the proportion of high molecular weight. In addition, from the age of eight months, proteins with a molecular weight of 9.6-14.2 kDa and $75 \mathrm{kDa}$ disappear in the basolateral membrane. Instead, proteins with a molecular weight of $300 \mathrm{kDa}$ and $170-1885 \mathrm{kDa}$ are appeared. In addition, in the apical membranes of enterocytes there is a significant decrease in the content of low molecular weight protein fractions and an increase in polypeptides with a molecular weight greater than $100 \mathrm{kDa}$. The appearance in the apical membranes of jejunum enterocytes of calves from eight months of age embryonic development of fractions of polypeptides with molecular weight of $24 \mathrm{kDa}$ and $66 \mathrm{kDa}$, which are present until the end of the fetal period.
\end{abstract}

Key words: polypeptides, jejunum intestine, enterocytes, apical membrane, basolateral membrane.

\section{Citation:}

Masiuk, D. M. (2020). Expression of plasmolemma proteins of the absorptive enterocytes of the cattle in the late fetal period. Ukrainian Journal of Veterinary and Agricultural Sciences, 3(1), 52-57.

\section{Introduction}

The key differences between the protein and lipid compositions of the apical and basolateral surfaces of enterocytes provide various functions, in particular, the apical surface is directed to the lumen of the intestine and provides transport, whereas the basolateral one interacts with other cells and the bloodstream (St Johnston \& Sanson, 2011). However, the polarization of the epithelial cells is not limited to the separation of the two domains of the plasma membranes, it also involves the orientation of cytosolic organelles and the cytoskeleton, with actin microfilaments stabilizing microvilli in the apical part of the epithelial cells (Tilney et al., 1973).

The functional differences of various membrane domains are based on the features of the polypeptide and lipid composition (Rodriguez-Boulan \& Powell, 1992). In particular, the cholesterol and sphingolipids are concentrated mainly in the apical membrane, whereas in the basolateral phosphatidylcholine (Simons \& van Meer, 1988). Integrins concentrated in the basolateral domain facilitate the formation of cell contacts, and the hydrolases of the apical membrane of the intestine cells provide digestion. Differences in the protein and lipid composition of the two membrane domains are provided by highly specific mechanisms (Caplan, 1997). It is established that the plasma membrane of enterocytes undergoes molecular differentiation during fetal development, which expresses several basic stage-specific polypeptides (Masiuk, 2019). Immunoblotting has shown that individual apical membrane polypeptides of the small intestine epithelium of calves exhibit the ability to selectively bind immunoglobulins at birth. Based on the obtained data, the hypothesis of receptorendocytotic mechanism of colostrum immunity formation in 
cattle was proposed (Tsvilikhovskyi et al., 1998). However, there are no data regarding the structural proteins of the plasmolemma of the jejunum absorptive enterocytes of the cattle in the early fetal period are absent. The purpose of the work is to establish the expression of plasmolemma proteins of the jejunum absorptive enterocytes of cattle in the late fetal period.

\section{Materials and methods}

The studies used 80 fetuses of cattle (Holstein breed), five, eight and nine months old, obtained from clinically healthy cows during forced slaughter. The age of the fetal was determined by the weight and length of the body, as well as the development of skin derivatives according to A. P. Studencov (Studencov et al., 2000). Laboratory studies were conducted in the Scientific Research Centre of biosafety and environmental control agro-industrial complex of Dnipro SAEU (formerly named: problematic research laboratory of physiology and functional morphology of productive animals of the DSAU) and the problematic scientific laboratory of internal diseases of animals of the National University of Life and Environmental Sciences of Ukraine, Kyiv.

After euthanasia of the fetus, the abdominal section was dissected and the jejunum intestine was isolated. Separation of the mesentery determined the length and middle of the intestine, removed the contents, and then selected part (30\% of the total length from the middle part of the organ), which was used to obtain isolated enterocytes. The experiments used a section of the intestine in the late fetal period (five, eight and nine months) $1.7 \mathrm{~m}$, which was twisted out of the mucosa or cut lengthwise and divided into small segments of $1.5-3 \mathrm{~cm}$ and washed thoroughly (4-5 times) cold (4$6{ }^{\circ} \mathrm{C}$ ) medium of the following composition: $120 \mathrm{mM} \mathrm{NaCl}$ and $1 \mathrm{mM}$ HEPES, the $\mathrm{pH}$ was adjusted to 7.4 used the dry Trice.

The basis for the selection of intestinal cells was the chemical (citrate/EDTO) method (Tomchuk et al., 1994), on the basis of which an author's modification of the method was developed (Masiuk, 2004). The quality of the obtained epithelial cells was evaluated by morphological and functional parameters.

To obtain apical and basolateral membranes from the suspension of isolated jejunum enterocytes of the cattle fetus, we used the basic differential centrifugation technique (Tsvilikhovskyi et al., 1989) in our modification (Masiuk, 2004).

The amount of total protein in membrane preparations was determined by the Lowry method in Miller modification. Studies on the content and composition of the structural proteins of enterocytes plasmalemma were performed according to the method described by Laemmli using $1 \mathrm{~mm}$ thick polyacrylamide gel electrophoresis (Vlizlo et al., 2012).

Experimental studies have been conducted to comply with the requirements of Law of Ukraine No. 3447 - IV of 21.02.06 "On the Protection of Animals from Cruelty" and are consistent with the basic principles of the "European Convention for the Protection of Vertebrate Animals Used for Experimental and Scientific Purposes" (Strasbourg, 1986), the "Declaration on the Humane Treatment of Animals" (Helsinki, 2000) and the National Congress on Bioethics "General Ethical Principles for Experiments on Animals" (Kyiv, 2001).

The obtained numerical data were statistically processed: the arithmetic mean $(\mathrm{M})$; its error $(\mathrm{m})$ were determined the probability of differences of the mean values was established by Student's criterion.

\section{Results and discussion}

In the late fetal period, 31 and 27 protein fractions of apical and basolateral membranes, respectively, were found in the plasmalemma of the jejunum intestine enterocytes, which had a molecular weight of $9.6 \mathrm{kDa}$ to $300 \mathrm{kDa}$.

Dynamics of concentration of apical membrane enterocyte polypeptides in late fetal period. According to electrophoresis, 29 protein fractions were detected in the apical membranes of enterocytes five-month-old cattle fetus (Fig. 1).

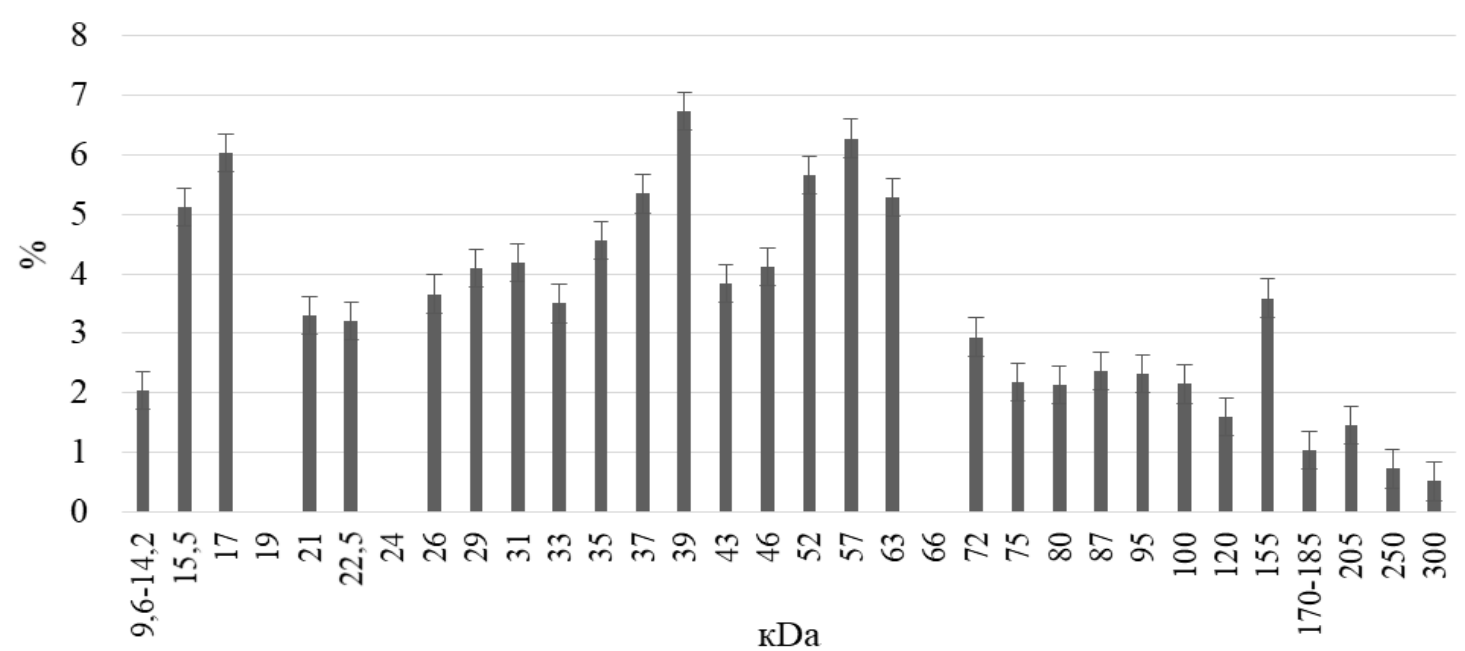

Fig. 1. Structural proteins of the apical membrane of the jejunum enterocytes of five-months-old cattle fetus $(M \pm m ; \% ; n=6)$

It should be noted that protein fractions with low molecular weight (up to $24 \mathrm{kDa}$ ) were only $19.7 \%$, in particular, proteins with a molecular weight of 9.6-14.2 $\mathrm{kDa}$ were $2.04 \pm 0.01 \% ; 15.5 \mathrm{kDa}-5.11 \pm 0.05 \% ; 17 \mathrm{kDa}-$ $6.03 \pm 0.04 \% ; 21 \mathrm{kDa}-3.31 \pm 0.04 \%$ and $22.5 \mathrm{kDa}-$
$3.21 \pm 0.02 \%$. Protein fractions with a molecular weight from $24 \mathrm{kDa}$ to $100 \mathrm{kDa}$ were $69.2 \%$, in particular, proteins with a molecular weight of $26 \mathrm{kDa}$ were $3.66 \%, 29 \mathrm{kDa}-$ $4.10 \%, 31 \mathrm{kDa}-4.19 \%, 33 \mathrm{kDa}-3.50 \%, 35 \mathrm{kDa}-$ $4.56 \%, 37 \mathrm{kDa}-5.34 \%, 39 \mathrm{kDa}-6.73 \%, 43 \mathrm{kDa}-$ 
$3.83 \%, 46 \mathrm{kDa}-4.12 \%, 52 \mathrm{kDa}-5.66 \%, 57 \mathrm{kDa}-$ $6.27 \%, 63 \mathrm{kDa}-5.28 \%, 72 \mathrm{kDa}-2.94 \%, 75 \mathrm{kDa}-$ $2.19 \%, 80 \mathrm{kDa}-2.14 \%, 87 \mathrm{kDa}-2.37$ and $95 \mathrm{kDa}-$ $2.32 \%$. Protein fractions with a molecular weight of $100 \mathrm{kDa}$ or more were detected - only $11.1 \%$ of the total number of polypeptides. Thus, polypeptides with a molecular weight of $100 \mathrm{kDa}$ are $2.15 \pm 0.01 \% ; 120 \mathrm{kDa}-1.61 \pm$ $0.01 \% ; 155 \mathrm{kDa}-3.59 \pm 0.02 \% ; 170-185 \mathrm{kDa}-1.04 \pm$ $0.01 \% ; 205 \mathrm{kDa}-1.46 \pm 0.01 \% ; 205 \mathrm{kDa}-0.73 \pm 0.01 \%$; $205 \mathrm{kDa}-0.52 \pm 0.01 \%$. Proteins of the apical membrane of the cattle jejunum enterocytes with a molecular weight greater than $300 \mathrm{kDa}$ were not detected by electrophoresis.

According to the results obtained up to eight months of age of cattle fetus, the spectrum of protein fractions of the apical membrane of enterocytes does not change significantly, but their ratio changes. The proportion of low-molecularweight proteins in the apical membrane of the jejunum enterocytes decreases to $14.7 \%$ (Fig. 2). In the apical mem- branes of jejunum enterocytes of eight-month-old cattle fetus, fractions of polypeptides with molecular weights from $24 \mathrm{kDa}$ to $100 \mathrm{kDa}$ are $70.4 \%$. Protein fractions with a molecular weight greater than $100 \mathrm{kDa}-14.6 \%$.

At the last stage of prenatal development of the fetus, significant changes occur in the polypeptide composition of the apical membranes of enterocytes (Fig. 3). Thus, from eight to nine months of fetus age, the number of lowmolecular-weight proteins in the apical membrane of the jejunum enterocyte decreases to $11.7 \%$, which is significantly less on $3.0 \%$ according to these indicators at the eight-month age. Note the decrease in the proportion of polypeptides with a molecular weight of $15.5 \mathrm{kDa}$ and $17 \mathrm{kDa}$, respectively, on 1.55 times $(\mathrm{P} \leq 0.001)$ and 1.43 times $(\mathrm{P} \leq 0.001)$, and the content of proteins with a molecular weight of 9.6-14.2 $\mathrm{kDa}$ and $21 \mathrm{kDa}$ significantly increased on 1.49 times $(\mathrm{P} \leq 0.001)$ and 1.10 times $(\mathrm{P} \leq 0.05)$, respectively.

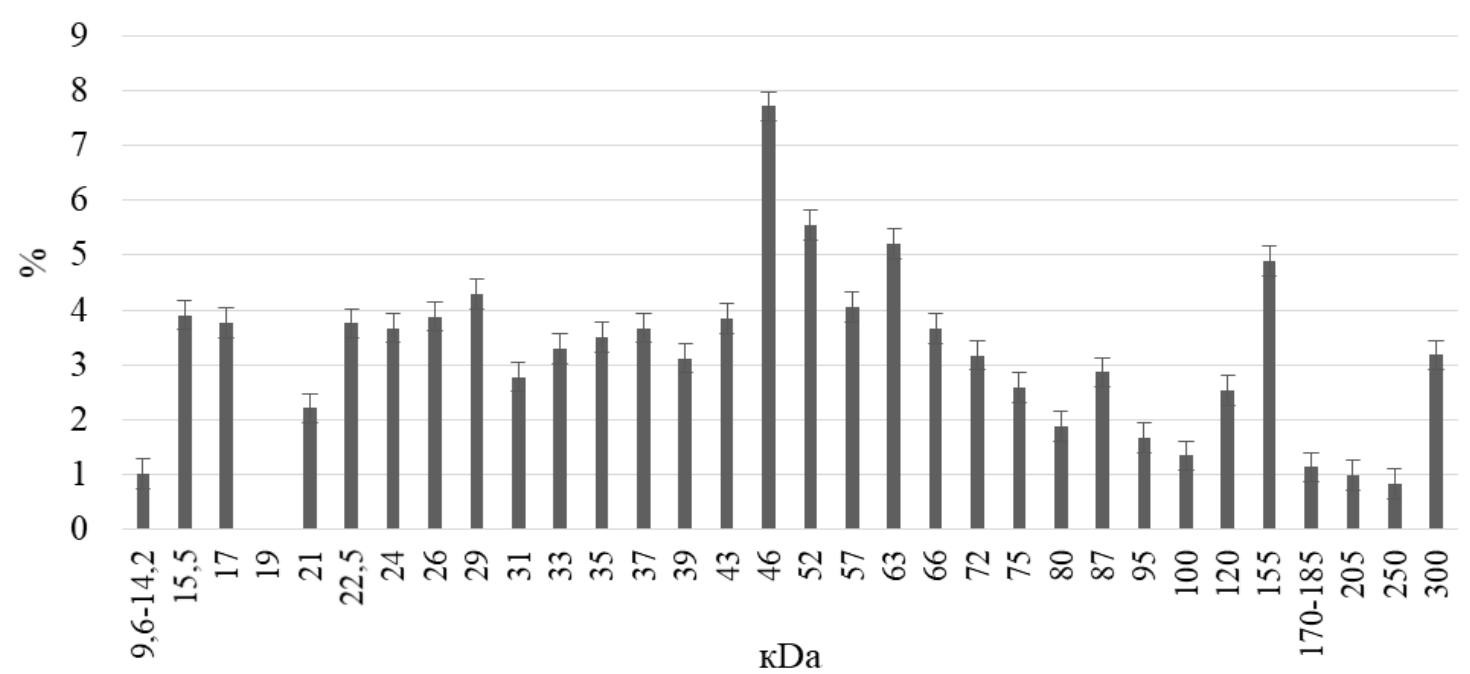

Fig. 2. Structural proteins of the apical membrane of the jejunum enterocytes of eight-month-old cattle fetus $(M \pm m ; \% ; n=6)$

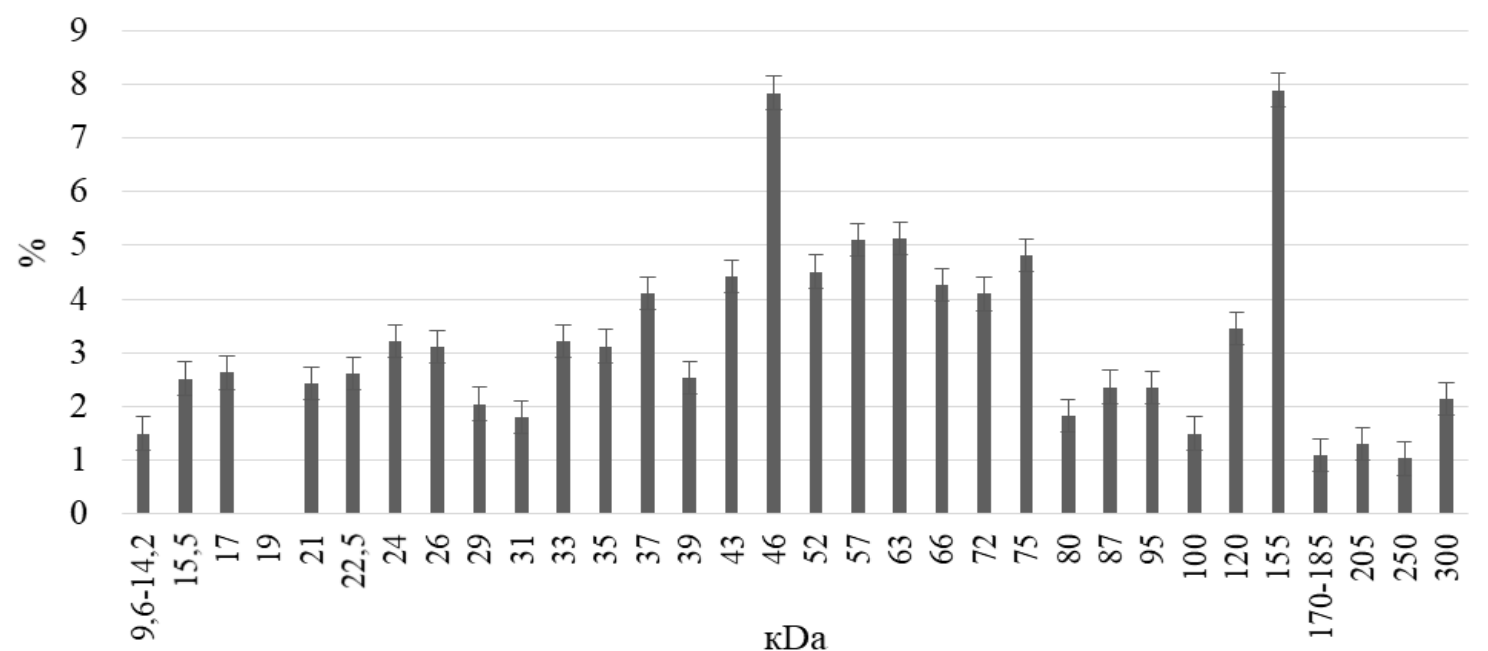

Fig. 3. Structural proteins of the apical membrane of the jejunum enterocytes of nine-month-old cattle fetus $(M \pm m ; \% ; n=6)$

In the apical membranes of the jejunum enterocytes of nine-month-old cattle fetus fractions of polypeptides with a molecular weight of $24 \mathrm{kDa}$ to $100 \mathrm{kDa}$, almost $70 \%$, which is not significantly different from the previous study. However, significant changes in the portion of each of these fractions were established, in particular, up to the nine months of age an increase of the fraction of proteins with a molecular weight of $37 \mathrm{kDa}$ by 1.12 times $(\mathrm{P} \leq 0.05)$,
$43 \mathrm{kDa}-1.15$ times $(\mathrm{P} \leq 0.05), 57 \mathrm{kDa}-1.26$ times $(\mathrm{P} \leq 0.001), 66 \mathrm{kDa}-1.17$ times $(\mathrm{P} \leq 0.01), 72 \mathrm{kDa}-1.29$ times $(\mathrm{P} \leq 0.001), 75 \mathrm{kDa}-1.86$ times $(\mathrm{P} \leq 0.001)$ and $95 \mathrm{kDa}-1.61$ times $(\mathrm{P} \leq 0.001)$, while reducing the proportion of polypeptides with a molecular weight of $26 \mathrm{kDa}$ by 1.25 times $(\mathrm{P} \leq 0.001), 29 \mathrm{kDa}-2.09$ times $(\mathrm{P} \leq 0.001)$, $31 \mathrm{kDa}-1.54$ times $(\mathrm{P} \leq 0.001), 35 \mathrm{kDa}-1.12$ times $(\mathrm{P} \leq 0.05), 39 \mathrm{kDa}-1.23$ times $(\mathrm{P} \leq 0.001), 52 \mathrm{kDa}-$ 
1.23 times $(\mathrm{P} \leq 0.001)$ and $87 \mathrm{kDa}$ respectively 1.22 times $(\mathrm{P} \leq 0.001)$.

The results of studies indicate that protein fractions with a molecular weight greater than $100 \mathrm{kDa}$ in the apical membranes of eight-month-old fetal enterocytes are $18.4 \%$, which is significantly higher than all the previous values obtained. This increase is due to the growth in the apical membrane, from eight to nine months of embryonic calf development, the percentage of polypeptides with a molecular weight of $100 \mathrm{kDa}$ by 1.11 times $(\mathrm{P} \leq 0.05), 120 \mathrm{kDa}-$ 1.36 times $(\mathrm{P} \leq 0.001), 155 \mathrm{kDa}-1.61$ times $(\mathrm{P} \leq 0.001)$, $205 \mathrm{kDa}-1.32$ times $(\mathrm{P} \leq 0.001)$, and $250 \mathrm{kDa}-1.24$ times $(\mathrm{P} \leq 0.001)$, moreover, at the same time, there is a decrease in the percentage of proteins with a molecular weight of $300 \mathrm{kDa} 1.49$ times

Dynamics of enterocyte basolateral membrane polypeptides concentration in late fetal period. The analysis of our studies shows that 25 protein fractions with a molecular weight of 9.6 to $155 \mathrm{kDa}$ were detected in the basolateral membranes of the enterocytes of five-month-old cattle fetus (Fig. 4). A large proportion of the detected protein fractions belonged to low molecular weight polypeptides $(9.6-24 \mathrm{kDa}$ $-40.26 \%$ ). Thus, proteins with a molecular weight of 9.6$14.2 \mathrm{kDa}$ were $14.97 \pm 0.09 \% ; 15.5 \mathrm{kDa}-4.98 \pm 0.13 \%$; $17 \mathrm{kDa}-3.97 \pm 0.04 \% ; 19 \mathrm{kDa}-3.57 \pm 0.03 \% ; 21 \mathrm{kDa}-$ $7.81 \pm 0.08 \%$.

Regarding protein with a molecular weight 24-95 kDa, the majority of them are $55.2 \%$ in the basolateral membrane of the jejunum enterocytes of cattle fetus. Thus, proteins with a molecular weight of $24 \mathrm{kDa}-2.92 \pm 0.05 \% ; 26 \mathrm{kDa}$ $-5.57 \pm 0.03 \% ; 29 \mathrm{kDa}-3.33 \pm 0.03 \% ; 31 \mathrm{kDa}-4.33 \pm$ $0.03 \% ; 33 \mathrm{kDa}-4.35 \pm 0.04 \% ; 35 \mathrm{kDa}-2.91 \pm 0.02 \%$; $39 \mathrm{kDa}-1.48 \pm 0.03 \%, 43 \mathrm{kDa}-3.82 \pm 0.04 \%$; $46 \mathrm{kDa}-$ $3.82 \pm 0.03 \% ; 52 \mathrm{kDa}-3.75 \pm 0.04 \% ; 57 \mathrm{kDa}-5.88 \pm$ $0.06 \% ; 63 \mathrm{kDa}-4.41 \pm 0.03 \% ; 66 \mathrm{kDa}-3.53 \pm 0.04 \%$; $72 \mathrm{kDa}-2.41 \pm 0.03 \% ; 75 \mathrm{kDa}-1.35 \pm 0.01 \% ; 87 \mathrm{kDa}-$ $1.62 \pm 0.01 \%$.

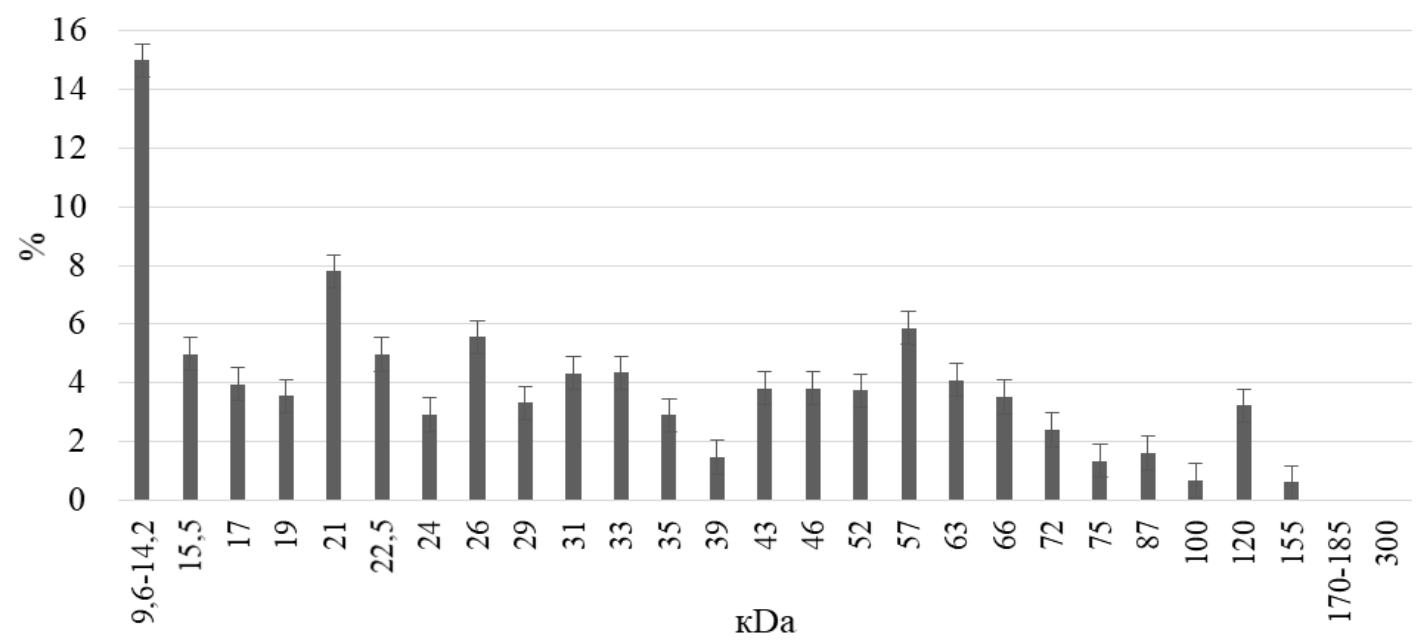

Fig. 4. Structural proteins of the basolateral membrane of the jejunum enterocytes of five-month-old cattle fetus $(\mathrm{M} \pm \mathrm{m} ; \% ; \mathrm{n}=6)$

It should be noted that protein fractions with molecular weights of $100 \mathrm{kDa}$ and more were found in the sum only $4.56 \%$. Thus, the proportion of polypeptides with a molecular weight of $100 \mathrm{kDa}$ was only $0.69 \pm 0.01 \%$, and proteins with a molecular weight of $120 \mathrm{kDa}$ and $155 \mathrm{kDa}$, respectively, $3.24 \pm 0.03 \%$ and $0.63 \pm 0.01 \%$. High molecular weight proteins greater than $155 \mathrm{kDa}$ were not detected in the basolateral membrane of the jejunum enterocyte by electrophoresis (unlike the apical membrane).
Analysis of the results of electrophoresis basolateral membrane proteins of the jejunum enterocytes of eightmonth-old cattle fetus indicates a significant increase in the proportion of protein fractions with a molecular weight of $100 \mathrm{kDa}$ and more up to $18.3 \%$. It should also be noted the appearance of polypeptides with a molecular weight of 170 $185 \mathrm{kDa}$ in basolateral membranes of enterocytes at the eighth month of embryonic development, which were not detected in previous months.

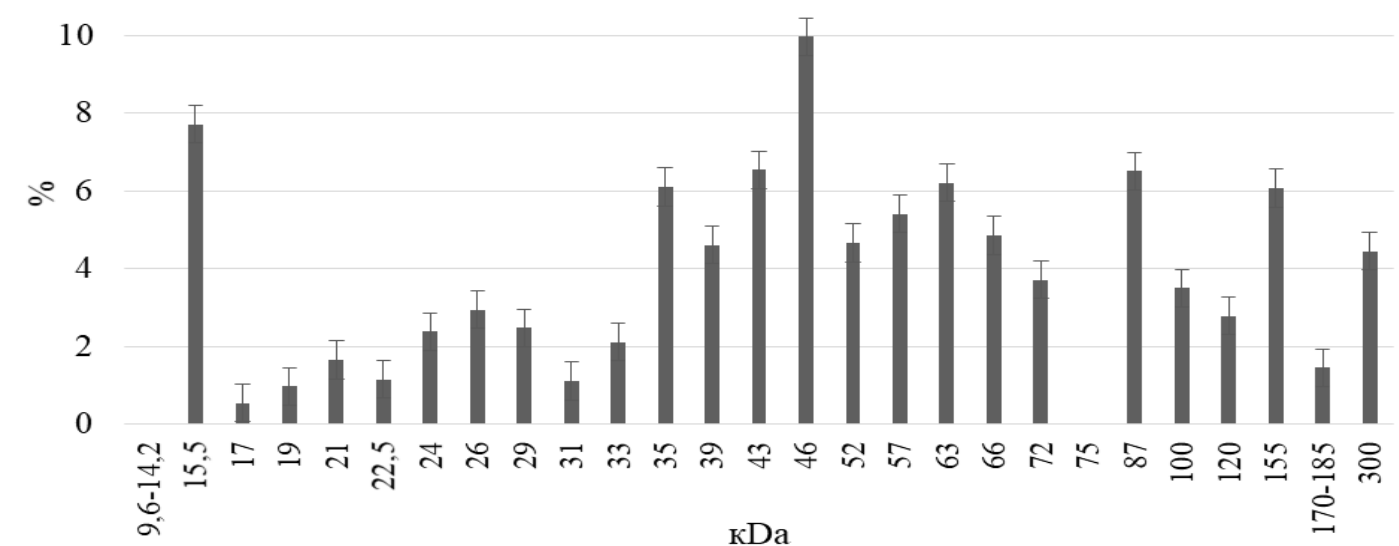

Fig. 5. Structural proteins of the basolateral membrane of the jejunum enterocytes of eighth-month-old cattle fetus $(\mathrm{M} \pm \mathrm{m} ; \% ; \mathrm{n}=6)$ 
From the eight to nine months of age of cattle fetus in the basolateral membrane of the jejunum enterocyte, the proportion of low molecular weight polypeptides does not change significantly and is $12.1 \%$ (Fig. 6). However, some of their redistribution according to molecular weight have been detected, in particular, the proportion of proteins with a molecular weight of $17 \mathrm{kDa}$ decreased by 1.77 times $(\mathrm{P} \leq 0.001), 19 \mathrm{kDa}-4.04$ times $(\mathrm{P} \leq 0.001)$ and $22.5 \mathrm{kDa}-$ 2.83 times $(\mathrm{P} \leq 0,001)$ compared to the 8 -month cattle fetus. In contrast, the proportion of proteins with a molecular weight of $15.5 \mathrm{kDa}$ and $21 \mathrm{kDa}$ significantly increased by 1.19 times $(\mathrm{P} \leq 0.01)$.
From eight to nine months of age of cattle fetus, there is a slight decrease in the basolateral membrane of enterocytes, the proportion of polypeptides with a molecular weight of 24-95 kDa to $65.8 \%$, according to the total number of proteins. It should be noted that in the basolateral membranes of enterocytes from eight to nine months of age decreased the proportion of proteins with a molecular weight of $26 \mathrm{kDa}$ (1.48 times; $\mathrm{P} \leq 0.001), 29 \mathrm{kDa}$ (1.53 times; $\mathrm{P} \leq 0.001)$, $35 \mathrm{kDa}(1.21$ times; $\mathrm{P} \leq 0.001)$ and $46 \mathrm{kDa}$ (1.98 times; $\mathrm{P} \leq 0.001)$. However, the proportion of proteins with a molecular weight of $43 \mathrm{kDa}$ increased by 1.26 times $(\mathrm{P} \leq 0.001), 52 \mathrm{kDa}-1.22$ times $(\mathrm{P} \leq 0.01)$, and $87 \mathrm{kDa}-$ 1.15 times $(\mathrm{P} \leq 0.05)$.

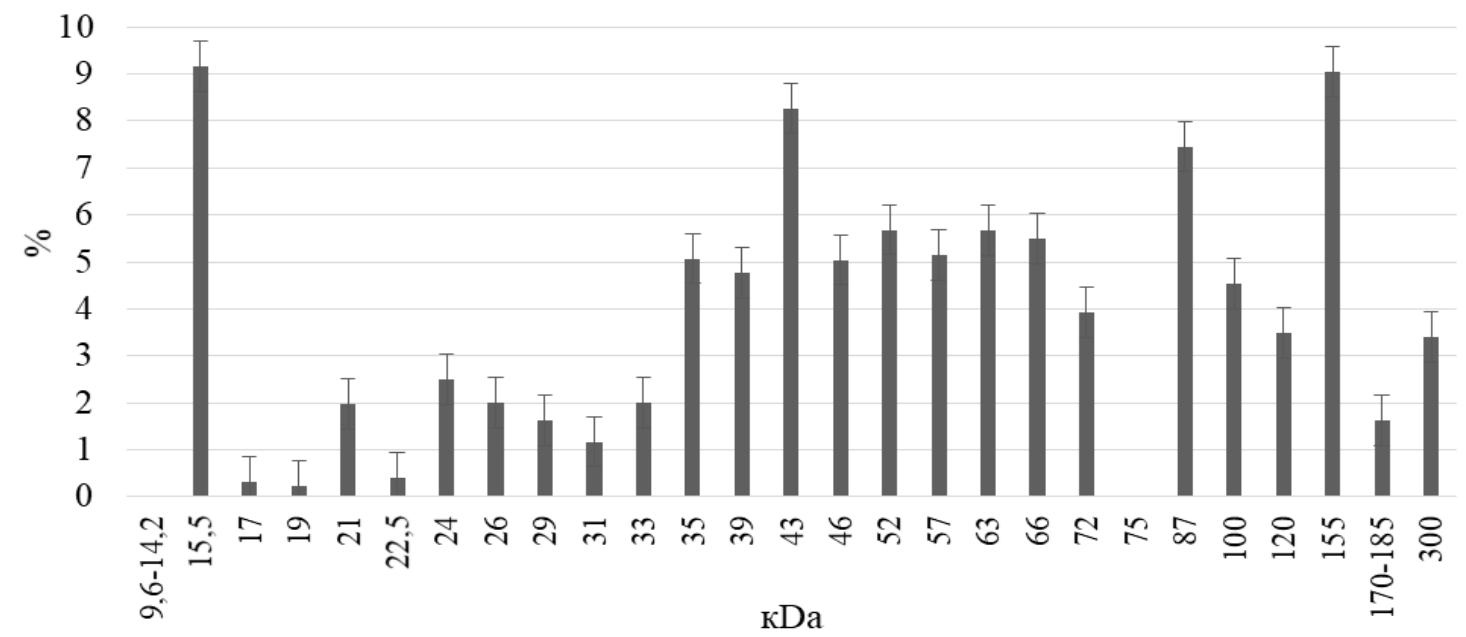

Fig. 6. Structural proteins of the basolateral membrane of the jejunum enterocytes of nine-month-old cattle fetus $(\mathrm{M} \pm \mathrm{m} ; \% ; \mathrm{n}=6)$

Analysis of the basolateral membrane proteins of the jejunum enterocytes of nine-months-old of cattle fetus shows a significant increase in the proportion of protein fractions with a molecular mass of $100 \mathrm{kDa}$ and more up to $22.1 \%$, in particular, there was an increase in the proportion of polypeptides with a molecular weight of $100 \mathrm{kDa}$ by 1.29 times $(\mathrm{P} \leq 0.001), 120 \mathrm{kDa}-1.25$ times $(\mathrm{P} \leq 0.001), 155 \mathrm{kDa}-$ 1.49 times $(\mathrm{P} \leq 0.001)$ and $170-185 \mathrm{kDa}-1.12$ times $(\mathrm{P} \leq 0.05)$ according to the indicators of embryos at eight months of age. It should also be noted that the proportion of proteins with a molecular weight of $300 \mathrm{kDa}$ by 1.31 times $(\mathrm{P} \leq 0.001)$ in basolateral membranes compared to that in eight-month-old fetus.

Therefore, analysis of the results of studies of the membrane proteins of cattle enterocytes in late fetal period indicates significant changes in their polypeptide composition.

\section{Conclusions}

In the late fetal period, 31 and 27 protein fractions of apical and basolateral membranes were found in the plasmalemma of the jejunum intestine, which had a molecular weight of $9.6 \mathrm{kDa}$ to $300 \mathrm{kDa}$, respectively. Analysis of the results of studies of the membrane proteins of cattle enterocytes in late fetal period indicates significant changes in their polypeptide composition. In particular, in the basolateral membranes of enterocytes, the content of lowmolecular-weight protein fractions are decrease (3.3-fold; $\mathrm{P} \leq 0.001)$ and the increase in the high-molecular-weight fraction occur during the late fetal period. In addition, from the age of eight months, proteins with a molecular weight of
9.6-14.2 $\mathrm{kDa}$ and $75 \mathrm{kDa}$ disappear in the basolateral membrane. Instead, proteins with a molecular weight of $300 \mathrm{kDa}$ and $170-1885 \mathrm{kDa}$ are claimed. In addition, in the apical membranes of enterocytes there is a significant decrease in the content of low molecular weight protein fractions and an increase in polypeptides with a molecular weight greater than $100 \mathrm{kDa}$. The appearance in the apical membranes of jejunum enterocytes of calves from eight ages of embryonic development of fractions of polypeptides with molecular weight of $24 \mathrm{kDa}$ and $66 \mathrm{kDa}$, which are present until the end of the fetal period.

\section{References}

Caplan, M. J. (1997). Membrane polarity in epithelial cells: protein sorting and establishment of polarized domains. Am. J. Physiol., 272(4), 425-429. doi: 10.1152/ajprenal.1997.272.4.F425.

Masiuk, D. M. (2004). Features of fractionation of plasma membranes isolated from small intestine enterocytes of cattle. Bulletin of the National Agrarian University, 78, 125-129.

Masiuk, D. M. (2004). Methodological features of obtaining and structural characterization of isolated enterocytes of the small intestine epithelium of cattle. Bulletin of the National Agrarian University, 75, 148-152.

Masiuk, D. M. (2019). Structural proteins of plasmolemma of the jejunum absorbing enterocytes of cattle fetus in early fetal period. Ukrainian Journal of Veterinary and Agricultural Sciences, 2(3). 32-38. doi: 10.32718/ujvas2-3.08.

Rodriguez-Boulan, E., \& Powell, S. K. (1992). Polarity of epithelial and neuronal cells. Annu. Rev. Cell Biol., 8, 395-427. doi: 10.1146/annurev.cb.08.110192.002143.

Simons, K., \& van Meer, G. (1988). Lipid sorting in epithelial cells. Biochemistry, 27(17), 6197-6202. doi: 10.1021/bi00417a001. 
St Johnston, D., \& Sanson, B. (2011). Epithelial polarity and morphogenesis. Curr Opin Cell Biol, 23(5), 540-546. doi: 10.1016/j.ceb.2011.07.005

Studencov, A. P., Shipilov, V. S., Preobrazhenskij, O. N. i dr. (2000). Beremennost; Veterinarnoe akusherstvo, ginekologiya i biotekhnika razmnozheniya, Kolos (in Russian).

Tilney, L. G., Hatano, S., Ishikawa, H., \& Mooseker, M. S. (1973). The polymerization of actin: its role in the generation of the acrosomal process of certain echinoderm sperm. J. Cell Biol., 59(1), 109-126. doi: 10.1083/jcb.59.1.109.

Tomchuk, V. A., Usatiuk, P. V., Tsvilikhovskyi, M. I., \& Melnychuk, D. O. (1994). Otrymannia izolovanykh klityn epiteliiu tonkoho kyshechnyka velykoi rohatoi khudoby. Fiziolohichnyi zhurnal, 40(5/6), 45-51 (in Ukrainian).

Tsvilikhovskyi, M. I. (1998). Bilky plazmatychnoi membrany epiteliiu tonkoho kyshechnyka velykoi rohatoi khudoby: dys... d-ra biol. nauk: 03.00.04. Natsionalnyi ahrarnyi un-t. K., 317 (in Ukrainian).

Tsvilikhovskyi, N. I. (1989). Vydelenie apikalnoj i bazolateralnoj membran enterocita tonkoj kishki krupnogo rogatogo skota $i$ strukturno-funkcional\&apos;nye izmeneniya $\mathrm{V}$ nih pri patologii. Fiziol. Zhurn., 35(5), 121 (in Russian).

Vlizlo, V. V., Fedoruk, R. S., \& Ratych, I. B. (2012). Laboratorni metody doslidzhen $\mathrm{u}$ biolohii, tvarynnytstvi ta veterynarnii medytsyni. Dovidnyk. Lviv. SPOLOM (in Ukrainian). 